\title{
Research Article \\ INFLUENCE OF PERSE PERFORMANCE, COMBINING ABILITY AND HETEROSIS IN CROSSES INVOLVING DIVERSE OKRA (Abelmoschus esculentus L. MOENCH) CULTIVARS FOR YIELD RELATED TRAITS
}

\section{ESWARAN R. ${ }^{*}$ AND ANBANANDAN V.}

Department of Genetics and Plant Breeding, Faculty of Agriculture, Annamalai University, Annamalai Nagar, 608002 Tamil Nadu, India. *Corresponding Author: Email-eswargene1@gmail.com

\author{
Received: February 21, 2018; Revised: February 25, 2018; Accepted: February 26, 2018; Published: February 28, 2018
}

\begin{abstract}
Three Indian varieties, two exotic cultures and one indigenous culture of Okra were self-pollinated for one generation and crossed in a diallel design to study the influence of perse performance, combining ability and heterosis for fruit yield per plant. The crosses with Indian $\times$ Indian and Indian $\times$ Exotic lines showed high fruit yield per plant. The best cross combination Arka Anamika $\times$ Parbhani Kranti were selected as the best performing hybrids of which the Indian varieties are involved in this cross. The next cross combinations Parbhani Kranti $\times$ EC-112112 and Parbhani Kranti $\times$ EC-305626 were selected as best hybrids of which both the Indian varieties and the exotic cultures are involved in producing these crosses.
\end{abstract}

Keywords- Okra, perse performance, Combining Ability, Heterosis.

Citation: Eswaran R. and Anbanandan V. (2018) Influence of Perse Performance, Combining Ability and Heterosis in Crosses Involving Diverse Okra (Abelmoschus esculentus L. Moench) Cultivars for Yield Related Traits. International Journal of Agriculture Sciences, ISSN: 0975-3710 \& E-ISSN: 0975-9107, Volume 10, Issue 4, pp.5220-5222.

Copyright: Copyright@2018 Pervaiz A.P. This is an open-access article distributed under the terms of the Creative Commons Attribution License, which permits unrestricted use, distribution and reproduction in any medium, provided the original author and source are credited.

Academic Editor / Reviewer: Oluk Aylin C., M P Wankhade

\section{Introduction}

Okra (Abelmosclus esculeutus (L.) Moench) an allopolyploidy [12] belongs to the family Malvaceae an important vegetable crop grown in tropical and sub-tropical regions of Asia, Africa, America and temperate regions of Mediterranean basin [7]. In India it is cultivated in 3.76 lakh hectares with annual production of 36.84 lakh tones and average productivity of 9.80 tonnes per hectare [1]

Okra is a self-pollinated crop and it is the cheapest and best vegetable crop [5] and plays a significant role in the rural economies, where it is cultivated, attention needs to be directed to the selection of high yielding cultivars [4] and it has a suitable mechanism to produce hybrid seed at a commercial scale. Hence, exploitation of heterosis has been attempted and hybrid vigour has been reported with as much as $86 \%$ increased yield [3]. Combining ability of the parents is becoming increasingly important in plant breeding, especially in hybrids [11]. Information on the general and specific combining abilities will be useful to plan breeders in interpreting the genetic basis of the traits concerned.

In this present study, the potential Indian varieties and the exotic genotypes were selected and crossed in dialled fashion. The main objective is to compare the breeding potential of the Indian and exotic line and to identify the superior $F_{1}$ combination. This in turn will be very much useful in strengthening the ongoing efforts on developing superior $F_{1}$ cross combinations.

\section{Materials and Methods}

The present investigation was undertaken in the Department of Genetics and Plant Breeding Farm, Faculty of Agriculture, Annamalai University. The parents were selected accordingly to provide a substantial amount of genetic diversity. Three Indian varieties (Akra Anamika (P1), Parbhani Kranti (P2) and Pusa Sawani (P3)), two exotic cultures (EC-112112 (P4) and EC-305626 (P5)) and one indigenous culture (IC-128076 (P6)) were chosen.

These six genotypes were crossed in a diallel mating systems to produce 30 hybrids. These 30 hybrids and six parents were evaluated to assess its field performance in randomized back design with three replications. Each cross combination with their parents were sown in three rows and from these rows five random parents were selected for recording yield and yield related traits, ie, number of branches per plant, plant height, number of fruits per plant, fruit weight and fruit yield per plant.

The mean values of each entry were used for analysis of variance. These mean values were also used for calculating heterosis over mid parental value, and the significant of heterosis was tested using the formula given [15]. The scroes of +1 and -1 were given to GCA values which is being significant in desirable directions, while the score zero was given to non-significant GCA values.

The data obtained on the diallel crosses were analysed by using the combining ability analysis by Griffing (1956b) method II model I (fixed) [6].

\section{Results and Discussion}

This study mainly focuses on the fruit yield per plant since this was considered as the prime most important factor in Okra productivity. The Perse performance, SCA effects and heterotic values are presented in [Table-1], when compared all the crosses represent a wide variation in terms of fruit yield per plant ranging from $318.26-685.31(\mathrm{~g})$ per plant were observed. Of these, the cross combinations Akra Anamika x Parbhani Kranti (648.58g), Parbhani Kranti x EC-305626 (648.58g) Parbhani Kranti $\times$ EC-112112 (617.84g) and Arka Anmika $\times$ Pusa Sawani $(563.27 \mathrm{~g})$ recorded high fruit yield per plant respectively. Of these best crosses between the Indian variety Parbhani Kranti combines with the exotic cultures of EC-305626 and EC-112112 to produce the best $F_{1}$ hybrids. Although these two cross combinations did not yield highest fruit yield per plant in this investigation, they captured second and third place in their economic yield. This indicates the need for utilizing exotic lines in the genetic improvement of Okra. This is in agreement with [13,8-10].earlier reports. 
Out of 15 crosses generated, nine cross combination revealed significant positive heterosis for fruit yield per plant. This suggests the importance of dominance and the dominant favourable alleles in determining the performance of the $F_{1}$ generation. When considered heterosis alone it is misleading, because the cross combinations which exhibited highest heterosis did not portrayed the best perse performance and vice-versa. This may be due to the variability which is present in the parental expression for this trait.

The SCA effects were found to be higher in highest yielding cross Arka Anamika $\times$ Parbhani Kranti and similarly for the next high yielding combinations. This type of trend were also found in the low yielding cross combinations, where in the SCA values are low. Similar observations were [14,2] reported.

Table-1 Performance of Per se, SCA effect and the level of Heterosis for fruit yield per plant of different crosses in Okra

\begin{tabular}{|c|c|c|c|c|}
\hline $\begin{array}{l}\text { S. } \\
\text { NO }\end{array}$ & Crosses & $\begin{array}{c}\text { Per se } \\
\text { Performance }\end{array}$ & $\begin{array}{c}\text { SCA } \\
\text { effects }\end{array}$ & Heterosis(\%) \\
\hline 1 & $\mathrm{P} 1 \times \mathrm{P} 2$ & 685.31 & $104.65^{* *}$ & $47.03^{* *}$ \\
\hline 2 & $\mathrm{P} 1 \times \mathrm{P} 3$ & 563.27 & $62.34^{* *}$ & $34.28^{\star *}$ \\
\hline 3 & $\mathrm{P} 1 \times \mathrm{P} 4$ & 358.39 & $105.67^{* *}$ & $-19.73^{* *}$ \\
\hline 4 & $\mathrm{P} 1 \times \mathrm{P} 5$ & 377.04 & $-66.24^{* *}$ & $-11.10^{* *}$ \\
\hline 5 & $\mathrm{P} 1 \times \mathrm{P} 6$ & 391.12 & $-35.97^{\star *}$ & -2.77 \\
\hline 6 & $\mathrm{P} 2 \times \mathrm{P} 3$ & 318.26 & $176.65^{* *}$ & $19.47^{\star *}$ \\
\hline 7 & $\mathrm{P} 2 \times \mathrm{P} 4$ & 617.84 & $81.74^{\star *}$ & $46.34^{* *}$ \\
\hline 8 & $\mathrm{P} 2 \times \mathrm{P} 5$ & 648.58 & $98.12^{\star *}$ & $62.21^{* *}$ \\
\hline 9 & $\mathrm{P} 2 \times \mathrm{P} 6$ & 446.71 & $-29.37^{\star *}$ & $18.17^{\star \star}$ \\
\hline 10 & $\mathrm{P} 3 \times \mathrm{P} 4$ & 438.61 & $32.56^{* *}$ & $16.78^{* \star}$ \\
\hline 11 & $\mathrm{P} 3 \times \mathrm{P} 5$ & 499.23 & $41.77^{* \star}$ & $41.34^{* *}$ \\
\hline 12 & $\mathrm{P} 3 \times \mathrm{P} 6$ & 328.73 & -8.52 & -0.80 \\
\hline 13 & $\mathrm{P} 4 \times \mathrm{P} 5$ & 360.75 & $-78.56^{\star *}$ & $-5.12^{\star \star}$ \\
\hline 14 & $\mathrm{P} 4 \times \mathrm{P} 6$ & 511.03 & $-39.47^{* *}$ & $42.59^{* *}$ \\
\hline 15 & $\mathrm{P} 5 \times \mathrm{P} 6$ & 319.74 & $-18.08^{* *}$ & -4.85 \\
\hline
\end{tabular}

Significant at $5 \%$ level; ${ }^{*}$ Significant at $1 \%$ level

\section{General combining ability effects}

The estimates of general combining ability effects are presented in [Table-2]. For fruit yield per plant the parent Parbhani Kranti recorded highest GCA effect
(64.14), which indicated that Parbhani Kranti is the best choiced parent in hybridization for increasing fruit yield. The cross combination involving this parent will give a good result and such crosses can give a good superior segregating population. The parent Arka Anamika exhibited higher fruit yield per plant (31.67) next to the best performing parent. To develop a potential good superior segregating population, the crosses involving these two parents will yield a good result.

In any breeding programme, yield is the main objective and this yield is a trait resulting from the contributions of different yield components. The best cross combination Arka Anamika $\times$ Parbhani Kranti resulted in the contribution of the high GCA effects of the other yield contributing traits. To assess this, the overall assessments of GCA status based on the pooled scores of different economic traits are presented in [Table-3]. Based on the pooled scores of the GCA status, the parent Parbhani Kranti, emerged as the best combine followed by Arka Anamika, EC-112112 and EC-305626.

The performance of the best crosses, along with the contribution of combining ability effects and the heterosis percentage are presented in [Table-4]. Based on this the best cross Arka Anamika $\times$ Parbhani Kranti, had the parents with high GCA effects. Further, the magnitudes of SCA effects were also high, suggesting the possibility of exploiting heterosis. The superiority of other best performing cross combinations were also contributed by high GCA and effects of the parents involved and the proportion of SCA effects was higher than GCA effects of the parents.

When, the top four crosses are considered, three cross combinations involved the best combiner parent Parbhani Kranti as a common parent. The next best general combiner Arka Anamika involved in two cross combinations for getting higher yield per plant. If these the best general combiners namely Arka Anamika and Parbhani Kranti involved in producing the highest fruit yield per plant. The other parents which involved in producing the best hybrids with the best general combiners were Pusa Sawani, EC-12112 and EC-305626. In general, when the Indian varieties were combined it produces best result, because these varieties were developed with diverse parents. At the same time when we combine the Indian and the exotic cultures it also produces the best crosses for getting highest fruit yield per plant. These types of combinations would give a desirable segregate for more productivity in Okra breeding.

\begin{tabular}{|c|c|c|c|c|c|c|c|c|}
\hline \multicolumn{9}{|c|}{ Table-2 Estimates of general combining ability effects (GCA) for yield related traits in Okra } \\
\hline S. No. & Characters & AA & PK & PS & EC-112112 & EC-305626 & IC-128076 & S.C \\
\hline 1 & Number of branches per plant & $0.59^{* *}$ & $0.57^{* *}$ & $-0.24^{* *}$ & $0.12^{\star}$ & $-0.43^{* *}$ & $-0.60^{* *}$ & 0.04 \\
\hline 2 & Plant height & $-1.88^{* \star}$ & $5.88^{* \star}$ & $2.69^{* \star}$ & $-8.37^{* \star}$ & $-3.66^{* \star}$ & $5.34^{\star \star}$ & 0.81 \\
\hline 3 & Number of fruits per plant & $1.53^{* \star}$ & $3.04^{* *}$ & $-1.12^{* *}$ & $0.92^{* *}$ & 0.76 & $3.61^{* \star}$ & 0.23 \\
\hline 4 & Fruit weight & 0.18 & $0.73^{* *}$ & $-1.23^{* *}$ & -0.17 & $0.48^{*}$ & 0.01 & 0.17 \\
\hline 5 & Fruit yield per plant & $31.67^{* \star}$ & $64.14^{* *}$ & $-51.99^{* *}$ & $6.30^{* \star}$ & $9.60^{* *}$ & $-59.72^{\star \star}$ & 2.23 \\
\hline
\end{tabular}

\begin{tabular}{|c|c|c|c|c|c|c|c|c|c|c|}
\hline \multicolumn{10}{c|}{ Table-3 Pooled GCA effects of the parents in a diallel crosses of Okra } \\
\hline S. No. & Parents & NBPP & PH & NFPP & FW & FY & Total positive & Total negative & GCA status \\
\hline 1 & AA & +1 & +1 & +1 & 0 & +1 & 04 & I & H \\
\hline 2 & PK & +1 & +1 & +1 & +1 & +1 & 05 & - & $\mathrm{H}$ \\
\hline 3 & PS & -1 & -1 & -1 & -1 & -1 & - & 04 & $\mathrm{~L}$ \\
\hline 4 & EC-112112 & +1 & +1 & +1 & 0 & +1 & 04 & - & $\mathrm{H}$ \\
\hline 5 & EC-305626 & -1 & +1 & 0 & +1 & +1 & 03 & 1 & $\mathrm{H}$ \\
\hline 6 & EC-128076 & -1 & -1 & +1 & 0 & -1 & 1 & 03 & $\mathrm{~L}$ \\
\hline
\end{tabular}

\begin{tabular}{|c|c|c|c|c|c|c|}
\hline \multirow[b]{2}{*}{ S. No. } & \multirow[b]{2}{*}{ Cross } & \multirow[b]{2}{*}{ Yield (g) } & \multirow{2}{*}{ Heterosis (\%) } & \multicolumn{2}{|c|}{ GCA effect } & \multirow[b]{2}{*}{ SCA effect } \\
\hline & & & & $P(\mid s t)$ & $P(\|$ nd $)$ & \\
\hline 1 & $P_{1} \times P_{2}$ & 685.31 & 47.03 & 31.67 & 64.14 & 104.65 \\
\hline 2 & $P_{2} \times P_{5}$ & 648.58 & 62.21 & 64.14 & 9.60 & 98.12 \\
\hline 3 & $\mathrm{P}_{2} \times \mathrm{P}_{4}$ & 617.84 & 46.34 & 64.14 & 6.30 & 81.74 \\
\hline 4 & $P_{1} \times P_{3}$ & 563.27 & 34.28 & 31.67 & -51.99 & 62.34 \\
\hline
\end{tabular}

Conclusion: This study revealed that the Indian varieties performed well as a best combiner parent and it produces high fruit yield per plant than the exotic cultures

Application of Research: For developing high yielding genotypes in bhendi, breeders should give preference to Indian varieties rather than exotic cultures

Research Category: Genetics, Plant Breeding 


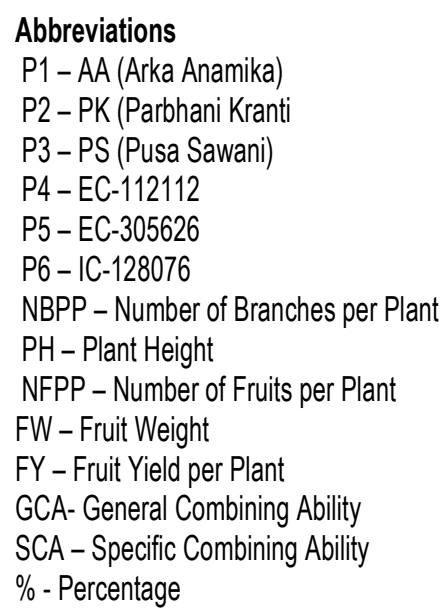

Acknowledgement: Authors are thankful to Department of Genetics and Plant Breeding, Faculty of Agriculture, Annamalai University, Annamalai Nagar, 608002 Tamil Nadu

\section{*Chairperson of Research: Dr R. Eswaran}

University: Annamalai University, Annamalai Nagar, 608002 Tamil Nadu

Research project name or number: Nil

Author Contribution: All author contributed equally

Author Statement: All authors read, reviewed, agree and approved the final manuscript

Ethical approval: This article does not contain any studies with human participants or animals performed by any of the authors.

\section{Conflict of Interest: None declared}

\section{References}

[1] Castanon-Cervantes O., Lugo C., Aguilar M., Gonzalez-Moran G. \& FanjulMoles M.L. (1995) Comp. Biochem. Phys. A., 110, 139-146.

[2] Ogle J.T. (1992) Invertebr. Reprod. Devel., 22, 267-274.

[3] Anonymus. (2006) Indian Horticulture Databased. Pp. 7-161.

[4] Dutta O.P. (1984) Breeding Okra for resistance to yellow mosaic virus and leaf curl virus. Annual Report of IIHR, Bangalore, 43.

[5] Elmaksoud M.A., Helai R.M. and Mohammed M.H. (1986) Am. Agric. Sci., 29(1), 431-438.

[6] Eshiet A.J. and Brisibe E.A. (2015) Adv Crop Sci Tech., 3, 197.

[7] Eswaran R., Thirugnana Kumar, S., Praveen Sampath Kumar, C., Anandan A. and Padmanaban. C. (2007) Plant Archives., 7(2), 721-724.

[8] Griffing B. (1956b) Australian J. Biol. Sci., 9,463-493.

[9] Khanarkar S.M. and Kathiria K.B. (2010) Electronic J. Plant Breeding, 1(4), 731-741.

[10] Muluken D., Wassu M. and Endale G. (2016) Journal of Applied Life Sciences International, 4(1), 1-12.

[11] Partap P.S., Dhankhat B.S. and Pandita M.C.(1981) Haryana J. Horti. Sci., 10(1-2), 122-127

[12] Patil Y.B., Madalagevi B.B., Patil S.S., Hosamani R.M. and Bivadat B.D. (1996) Karnataka J. Agric. Sci., 9(2), 294-300.

[13] Rajani B., Manju P., Manikantan Nair P. and Saraswathy P. (2001) J. Trop. Agric., 39, 98-101.

[14] Ramgiry M. and Singh S.V. (2017) Int. J. Pure App. Biosci. 5(2), 981-986.

[15] Singh S.P., Srivastava J.P., Singh J.N. and Singh M. P. (1977) Indian J. Agric. Sci., 47(11), 546-551.

[16] Sivagamasundari S., Irulappan,I., Arumugam R. and Jayasankar S. (1992) South Indian Agric., 40(1), $21-27$.

[17] Wynne J.C., Emery D.A. and Rice P.W. (1970) Crop sci., 10, 713-715. 